J. Dairy Sci. 99:3113-3123

http://dx.doi.org/10.3168/jds.2015-10462

(C) American Dairy Science Association ${ }^{\circledR}, 2016$.

\title{
Effects of the diacylglycerol o-acyltransferase 1 (DGAT1) K232A polymorphism on fatty acid, protein, and mineral composition of dairy cattle milk
}

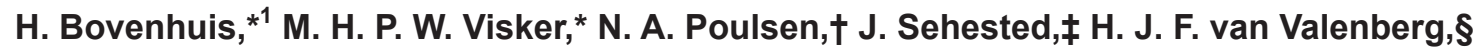 \\ J. A. M. van Arendonk, ${ }^{*}$ L. B. Larsen, $†$ and A. J. Buitenhuis\# \\ ${ }^{*}$ Animal Breeding and Genomics Centre, Wageningen University, PO Box 338, 6700 AH Wageningen, the Netherlands \\ †Department of Food Science, and \\ ‡Department of Animal Science, Aarhus University, PO Box 50, DK-8830 Tjele, Denmark \\ §Dairy Science and Technology Group, Wageningen University, PO Box 17, 6700 AA, Wageningen, the Netherlands \\ \#Center for Quantitative Genetics and Genomics, Department of Molecular Biology and Genetics, Aarhus University, PO Box 50 , \\ DK-8830 Tjele, Denmark
}

\begin{abstract}
Several studies have described associations between the diacylglycerol o-acyltransferase 1 (DGAT1) K232A polymorphism and routinely collected milk production traits but not much is known about effects of the DGAT1 polymorphism on detailed milk composition. The aim of this study was to estimate effects of the DGAT1 polymorphism on milk fatty acid, protein, and mineral composition. We looked for effects that were significant and consistent in Danish Holstein Friesian (HF), Danish Jersey, and Dutch HF as these are likely to be true effects of the DGAT1 K232A polymorphism rather than being effects of linked loci. For fatty acid composition, significant and consistent effects of the DGAT1 polymorphism were detected on C14:0, C16:0, C15:0, C16:1, C18:1 cis-9, conjugated linoleic acid (CLA) cis-9,trans-11, C18:2 cis-9, cis- 12 , and C18:3 cis9, cis-12,cis-15 content (percent by weight, wt/wt \%). For C16:0, C16:1, and C18:1 cis-9, the DGAT1 polymorphism explained more than $10 \%$ of the phenotypic variation. Significant effects on milk protein composition in Dutch HF could not be confirmed in Danish Jersey or Danish HF. For mineral content, significant and consistent effects of the DGAT1 polymorphism on calcium, phosphorus, and zinc were detected. In the Dutch HF population, the contribution of the DGAT1 K232A polymorphism to phenotypic variance was $12.0 \%$ for calcium, $8.3 \%$ for phosphorus, and $6.1 \%$ for zinc. Different from effects on fatty acid composition, effects of the DGAT1 polymorphism on yields of long-chain fatty acids C18:1 cis-9, CLA cis-9,trans-11, $\mathrm{C} 18: 2$ cis-9,cis-12, and C18:3 cis-9,cis-12,cis-15 were
\end{abstract}

Received September 29, 2015

Accepted December 29, 2015.

${ }^{1}$ Corresponding author: henk.bovenhuis@wur.nl not significant. This indicates that effects of DGAT1 on these fatty acids are indirect, not direct, effects: DGAT1 affects de novo synthesis of fatty acids and, consequently, the contribution of the long-chain fatty acids to total fat is decreased. In addition, effects of the DGAT1 polymorphism on yields of $\mathrm{Ca}, \mathrm{P}$, and $\mathrm{Zn}$ were not significant, which indicates that effects on these minerals are the result of indirect rather than direct effects of DGAT1: effects on calcium, phosphorus, and zinc content can be explained by effects of DGAT1 on milk volume. The reported effects of the DGAT1 polymorphism on fatty acid and mineral composition of milk are substantial and therefore relevant for milk quality.

Key words: diacylglycerol o-acyltransferase 1 (DGAT1), cattle, milk fatty acid composition, milk minerals

\section{INTRODUCTION}

Several studies have described associations between the diacylglycerol o-acyltransferase 1 (DGAT1) K232A polymorphism and routinely collected milk production traits (e.g., Grisart et al., 2002; Winter et al., 2002; Spelman et al., 2002; Thaller et al., 2003; Weller et al., 2003; Gautier et al., 2007; Berry et al., 2010). These studies show that the $K$ allele of the DGAT1 K232A polymorphism is associated with a higher fat content, protein content, and fat yield, but lower milk and protein yields. Less is known about the effects of the DGAT1 polymorphism on detailed milk composition. Schennink et al. (2007, 2008) showed that the $K$ allele is associated with smaller fractions of C14:0, unsaturated C18, and CLA, and a larger fraction of C16:0. Furthermore, Schopen et al. (2011) showed that the DGAT1 polymorphism is associated with $\alpha_{S_{1}}$ CN and $\alpha_{S_{2}} \mathrm{CN}$ content. Bijl et al. (2014) recently showed 
that the DGAT1 polymorphism is associated with $\alpha_{\mathrm{S}^{-}}$ 9P CN content but has no effect on $\alpha_{\mathrm{S1}}-8 \mathrm{P} \mathrm{CN}$ (where $\mathrm{P}$ indicates phosphorylation).

Bovenhuis et al. (2015) reported significant effects of the DGAT1 K232A polymorphism on lactose content of milk, with the $\mathrm{K}$ allele being associated with a higher lactose content. Lactose is a major contributor to the osmolarity of milk and as the osmolarity of milk is bound by biological constraints, it can be hypothesized that the DGAT1 polymorphisms also affects other contributors to the osmolarity of milk (e.g., the minerals $\mathrm{Na}^{+}, \mathrm{K}^{+}$and $\mathrm{Cl}^{-}$). Further, a major part of calcium, phosphate, and magnesium in milk is located in the casein micelle and contents of these milk minerals are proportional to protein content (e.g., Gaucheron, 2005). Therefore, effects of the DGAT1 polymorphism on protein yield and content might also result in changes of calcium, phosphate, and magnesium contents of milk. Effects of the DGAT1 polymorphism on mineral composition of milk have not been reported previously.

Within the context of the Dutch and Danish-Swedish Milk Genomic Initiatives, large numbers of bovine milk samples have been collected on Holstein Friesian (HF) and Jersey cattle, of which detailed fatty acid, protein and mineral composition are available. The unique phenotypes collected as part of both studies form the basis of the current study. The aim of the current study was to estimate the effect of the DGAT1 K232A polymorphism on milk fatty acid, protein, and mineral composition and to look for effects that are significant and consistent in Danish HF, Danish Jersey, and Dutch HF.

\section{MATERIALS AND METHODS}

\section{Animals}

In the Dutch Milk Genomic Initiative, morning milk samples were collected from 2,001 Dutch HF cows located on 398 herds throughout the Netherlands. Milk samples were collected in February and March 2005, and at least 3 cows per herd were sampled. The cows were all in parity 1, and between 63 and $282 \mathrm{~d}$ in lactation. All cows were housed in loose housing systems, fed according to standard practice, and milked twice a day. Further details about the experimental design can be found in Stoop et al. (2008). In this study, we only included animals that also had been genotyped for the DGAT1 K232A polymorphism.

In the Danish-Swedish Milk Genomic Initiative, morning milk samples were collected from Danish HF and Danish Jersey cows. The Danish HF milk samples were collected from 456 cows located on 20 dairy herds from October to December 2009. The Danish Jersey milk samples were collected from 436 cows located on
22 dairy herds from February to April 2010. From each herd, between 19 and 24 cows were sampled. The cows were in parity 1 to 3 and in mid lactation: Danish HF were 129 to $229 \mathrm{~d}$ in lactation and Danish Jersey were 130 to 252 in days in lactation. All cows were housed in loose housing systems, fed according to standard practice, and milked twice a day. Further details can be found in Poulsen et al. (2012).

\section{Milk Production Traits}

In the Dutch and the Danish experiments, fat, protein, and lactose contents were based on infrared spectroscopy measurements. The Dutch samples were analyzed using a MilkoScan FT6000 (Foss, Hillerød, Denmark) at the Milk Control Station (Qlip, Zutphen, the Netherlands), and the Danish samples using a MilkoScan FT2 (Foss) at Eurofins Laboratory (Holstebro, Denmark). Somatic cell count was determined using a Fossomatic 5000 (Foss), both in the Dutch and the Danish experiments. Somatic cell counts were logtransformed (base 2) to obtain SCS.

\section{Fatty Acid Composition}

Milk fatty acid (FA) composition in the Dutch experiment was measured by GC at the COKZ laboratory (Qlip, Leudsen, the Netherlands), as described by Schennink et al. (2007). Fatty acids were identified and quantified using pure methyl ester samples (SigmaAldrich, Larodan, Sweden). The FA were expressed as a proportion of total fat weight (wt/wt \%).

Milk FA composition in the Danish experiment was measured by GC as described by Larsen et al. (2011) and Poulsen et al. (2012). Fatty acids were identified and quantified via the use of external standards (Supelco 37 component FAME mix, Supelco Inc., Bellefonte, PA; GLC 469 methyl ester standard, Nu-Chek Prep Inc., Elysian, MN) and expressed as a proportion of total fat weight. The C18:1 trans isomers were not fully separated, and the peak assigned as C18:1 trans-11 was a mixture of trans-10 and trans-11 isomers.

\section{Protein Composition}

For the Dutch milk samples, the relative concentrations of $\alpha_{\mathrm{S}^{-}} \mathrm{CN}, \alpha_{\mathrm{S} 2}-\mathrm{CN}, \beta-\mathrm{CN}, \kappa-\mathrm{CN}, \alpha-\mathrm{LA}$, and $\beta$-LG were determined by capillary zone electrophoresis (CZE). Contents of the 6 major milk proteins were expressed as a percentage of the total protein fraction. The milk protein $\kappa$-CN consisted only of $\kappa-\mathrm{CN}-1 \mathrm{P}$ (nonglycosylated, monophosphorylated state). Heck et al. (2008) provides a detailed description of the CZE technique used to analyze the Dutch milk samples. 
For the Danish milk samples, the relative concentrations of $\alpha_{\mathrm{S}^{-}} \mathrm{CN}, \alpha_{\mathrm{S} 2}-\mathrm{CN}, \beta-\mathrm{CN}, \kappa-\mathrm{CN}, \alpha-\mathrm{LA}$, and $\beta-\mathrm{LG}$ were determined using the liquid chromatography/electrospray ionization-mass spectrometry (LC/ESI-MS) procedure as described in detail by Jensen et al. (2012) on skim milk. Contents of the 6 major milk proteins were expressed as a percentage of the total protein fraction based on UV signal at $214 \mathrm{~nm}$ and were the average of 2 measurements.

\section{Mineral Contents}

Milk mineral (Ca, Se, K, Mg, P, and Zn) concentrations in the Dutch milk samples were determined by inductively coupled plasma-atomic emission spectrometry (ICP-AES; Vista Axial, Varian, Australia) on whole milk as described by van Hulzen et al. (2009). For the Danish milk samples, milk minerals (Ca, Se, $\mathrm{K}, \mathrm{Mg}, \mathrm{P}$, and $\mathrm{Zn}$ ) were extracted from skim milk by acid sonication and identified using inductively coupled plasma mass spectrometry (ICP-MS) as described by Buitenhuis et al. (2015).

\section{Yields}

Samples from the Dutch experiment were used to estimate effects of the DGAT1 K232A polymorphism on FA, protein, and mineral yields. Yields of the FA were calculated by multiplying FA proportions (wt/wt \%) by kilograms of fat, yields of proteins were calculated by multiplying protein proportions (wt/wt \%) by kilograms of protein, and mineral yields were calculated by multiplying mineral concentrations (in $\mathrm{mg} / \mathrm{kg}$ or $\mu \mathrm{g} /$ $\mathrm{kg}$ ) by kilograms of milk. Total output of somatic cells was calculated by multiplying the SCC by kilograms of milk. Total output of somatic cells was log-transformed (base 2).

\section{Genotypes}

Genotypes for the DGAT1 K232A polymorphism were available for the Dutch cows and obtained as described by Schennink et al. (2007). For the Danish cows, genotypes of the DGAT1 K232A polymorphism were not available. Instead, the Danish HF and Danish Jersey cows were genotyped for SNP marker ARSBFGL-NGS-4939 (rs109421300) located on the bovine HD array (Illumina Inc., San Diego, CA) as described in detail by Buitenhuis et al. (2013). Based on linkage disequilibrium (LD) analysis performed in Haploview (Barrett et al., 2005), ARS-BFGL-NGS-4939 was located in a haplotype block covering the DGAT1 K232A location on the genome, suggesting complete LD between the 2 markers (data not shown). In the remainder of this paper, we will refer to genotypes based on the DGAT1 K232A polymorphism and the ARS-BFGL-NGS-4939 SNP as DGAT1 genotypes.

\section{Statistical Analysis}

The following model was used to estimate the effects of DGAT1 K232A genotypes in the Dutch HF population:

$$
\begin{aligned}
y_{k l m n o} & =\mu+\beta_{1} \operatorname{dim}_{\text {klmno }}+\beta_{2} e^{-0.05 \times \operatorname{dim}_{\text {klmno }}}+\beta_{3} \text { calmno }_{k l m o} \\
& +\beta_{4} \text { callmno }_{\text {klmo }}^{2}+\text { season }_{k}+\text { scode }_{l}+D G A T 1_{m} \\
& + \text { animal }_{n}+\text { herd }_{o}+e_{\text {klmno }}
\end{aligned}
$$

where $y_{k l m n o}$ is the observation; $\mu$ is the overall mean of the trait; $\operatorname{dim}_{k l m n o}$ is a covariate describing the effect of days in lactation, modeled with a Wilmink curve (Wilmink, 1987); $c a_{k l m n o}$ is a covariate describing the effect of age at first calving, season $n_{k}$ is the fixed effect of the $k$ th class of calving season [3 classes: summer (June-August 2004), autumn (September-November 2004), and winter (December 2004-February 2005)]; $s c o d e_{l}$ is the fixed effect accounting for possible differences in genetic level between proven bull daughters and young bull daughters; $D G A T 1_{m}$ is the fixed effect of the DGAT1 K232A genotype $(A A, A K$, or $K K)$; ani$m a l_{n}$ is the random additive genetic effect of animal $n$; $h^{2} d_{o}$ is the random herd effect of the oth herd; and $e_{k l m n o}$ is the random residual. The animal effects were assumed to be distributed as $N\left(\mathbf{0}, \mathbf{A} \sigma_{a}^{2}\right)$, herd effects as $N\left(\mathbf{0}, \mathbf{I} \sigma_{\text {herd }}^{2}\right)$, and the residuals were assumed to be distributed as $N\left(\mathbf{0}, \mathbf{I} \sigma_{e}^{2}\right)$, where $\mathbf{A}$ is the additive genetic relationships matrix, $\mathbf{I}$ is the identity matrix, $\sigma_{a}^{2}$ is the additive genetic variance, $\sigma_{\text {herd }}^{2}$ is the herd variance, and $\sigma_{e}^{2}$ is the residual variance. The $\mathbf{A}$ matrix was constructed based on 26,300 individuals. For minerals, model [1] was extended with a covariable representing the mineral concentration of the reference sample of the corresponding destruction run. In total, 105 reference values were obtained for Se and 101 for the other minerals (van Hulzen et al., 2009).

The model used to estimate the effects of DGAT1 K232A genotypes in the Danish HF or the Danish Jersey populations was

$$
\begin{aligned}
y_{k l m n} & =\mu+\beta_{1} \operatorname{dim}_{k l m n}+\text { parity }_{k}+D G A T 1_{l} \\
& + \text { herd }_{m}+\text { animal }_{n}+e_{k l m n}
\end{aligned}
$$

where $\operatorname{dim}_{k l m n}$ is a covariate describing the effect of days in lactation, parity $_{k}$ is the fixed effect of parity $(k=1$, 
2 , or 3), $D G A T 1_{l}$ is the fixed effect of the ARS-BFGLNGS-4939 genotype $(l=1,2$, or 3$)$, which is used as a proxy for the DGAT1 K232A genotype, and herd m $_{m}$ is the fixed effect of herd $(m=1, \ldots, 19$ for the Danish HF and $m=1, \ldots, 22$ for the Danish Jersey). Other model terms are as described for model [1]. The additive genetic relationships matrix for the Danish HF consisted of 4,811 animals and for the Danish Jersey of 4,351 animals.

Statistical analyses were based on records from animals with phenotypes and genotypes. There were small differences in number of records between traits, and the maximum number of records for Danish Jersey was 321, for Danish HF 371, and for Dutch HF 1,743. Analysis were performed using ASReml (Gilmour et al., 2009).

\section{RESULTS}

\section{Milk Production Traits}

Table 1 shows descriptive statistics of the Dutch and Danish milk samples. Average morning milk yield was $10.0 \mathrm{~kg}$ for Danish Jersey and $14.8 \mathrm{~kg}$ for Danish HF. Danish cows were in first, second, or third parity. Average morning milk yield for a first-parity Dutch HF was $13.6 \mathrm{~kg}$. Fat content for Danish Jerseys was $6.00 \%$, which was considerably higher than for Danish HF (3.99\%) or Dutch HF (4.35\%). Danish Jersey also had a higher protein content $(4.29 \%)$ than Danish HF (3.43\%) or Dutch HF (3.50\%). Lactose content was similar in Danish Jersey $(4.62 \%)$ and Dutch HF (4.63\%) and lower than in Danish HF (4.79\%). Somatic cell score was higher in Danish Jerseys (6.53) compared with Danish HF (6.02). First-parity Dutch HF cows had the lowest SCS (5.42).

Effects of the DGAT1 K232A polymorphism on routinely collected milk production traits, FA composition, protein composition, and mineral contents are shown in Table 2. Standard errors for AA genotype effects in Danish Jersey and $K K$ genotype effects in Danish HF were large because of small numbers of observations for these genotype classes. Effects on milk yield were significant in Danish Jersey and Dutch HF, and the $K$ allele was consistently associated with lower milk yields. Effects on milk yield were not significant in Danish HF. Effects of the DGAT1 polymorphism on fat content and protein content were highly significant and the $K$ allele was consistently associated with higher fat and protein contents. Only in Danish Jersey was a significant effect on lactose content detected, where the $K$ allele was associated with lower lactose content. Effects on SCS were not significant in any of the populations.

\section{FA Composition}

Contents (wt/wt \%) of C8:0 and C10:0 were similar in Danish HF and Dutch HF, whereas Danish Jersey had higher levels for these FA (Table 1). Mean C12:0 content was higher in Dutch HF than in Danish HF or Danish Jersey. Considerable differences between the 3 populations were observed for C16:0 content, with the highest levels in Dutch HF (32.62 wt/wt \%) and the lowest in Danish HF (28.86 wt/wt \%). Mean contents for the uneven chain FA C13:0, C15:0, and C17:0 were similar in the 3 populations. The unsaturated C16:1 content was also similar in the 3 populations; however, average C14:1 content in Dutch HF (1.34 wt/wt \%) was higher than in Danish HF (0.97 wt/wt $\%)$ or Danish Jersey (0.83 wt/wt \%). For C18:0 content, lowest levels were observed in Dutch HF (8.73 wt/wt \%) and higher levels in Danish HF (10.48) and Danish Jersey (11.74). For C18:1 cis-9 content, the highest levels were observed in Danish HF (20.07 wt/ wt \%) and lowest levels in Danish Jersey (16.59 wt/ wt \%). Relatively large differences in C18:1 trans-11 content were observed between Dutch HF (0.77 wt/ wt \%) on the one hand and Danish HF (1.69 wt/wt $\%)$ and Danish Jersey (1.54 wt/wt \%) on the other hand. Differences between the 3 populations in the content of n-3 FA C18:3 cis-9,cis-12,cis-15 were relatively small.

Effects of the DGAT1 K232A polymorphism on the contents of C14:0, C16:0, C15:0, C16:1, C18:1 cis-9, CLA cis-9,trans-11, C18:2 cis-9,cis-12, and C18:3 cis-9,cis-12,cis-15 were consistently significant across populations (Table 2). The $K$ allele was associated with higher contents of C16:0, C15:0 and C16:1, and lower contents of C14:0, C18:1 cis-9, CLA cis-9,trans-11, C18:2 cis-9,cis-12, and C18:3 cis-9,cis-12,cis-15. In the Dutch HF population, the contribution of the DGAT1 K232A polymorphism to the phenotypic variance (based on Table 1) was $8.6 \%$ for C14:0, $10.9 \%$ for C16:0, $3.6 \%$ for $\mathrm{C} 15: 0,13.1 \%$ for $\mathrm{C} 16: 1,10.4 \%$ for $\mathrm{C} 18: 1$ cis-9, $2.9 \%$ for CLA cis-9,trans-11, $2.5 \%$ for C18:2 cis-9,cis-12, and $2.2 \%$ for $\mathrm{C} 18: 3$ cis- 9 , cis- 12 , cis- 15 .

Effects of the DGAT1 polymorphism on FA yield showed that the $K$ allele was associated with higher total output of most FA (Table 2). Interestingly, the DGAT1 polymorphism had no significant effect on yields of C18:1 cis-9, CLA cis-9,trans-11, C18:2 cis9,cis-12, and C18:3 cis-9,cis-12,cis-15, whereas there were highly significant effects on these FA when expressed as percent by weight. The effect of the DGAT1 polymorphism on the yield of C14:0 was significant but effects were relatively small. 


\section{Protein Composition}

The 3 populations showed considerable differences in milk protein composition (Table 1). The Dutch HF population had higher $\alpha_{\mathrm{S}^{-}}-\mathrm{CN}$ and $\alpha_{\mathrm{S}^{2}} \mathrm{CN}$ contents compared with the Danish HF and Danish Jersey populations. The $\beta-\mathrm{CN}$ content was higher in Danish HF (36.01) than in Danish Jersey (28.33) and Dutch HF (27.20). The $\kappa$-CN content was lower in Dutch $\mathrm{HF}$; however, in the Dutch samples, the $\kappa-\mathrm{CN}$ frac-

Table 1. Means and standard deviations (in parentheses) for detailed milk composition in Danish Jersey, Danish Holstein Friesian (HF), and Dutch HF populations

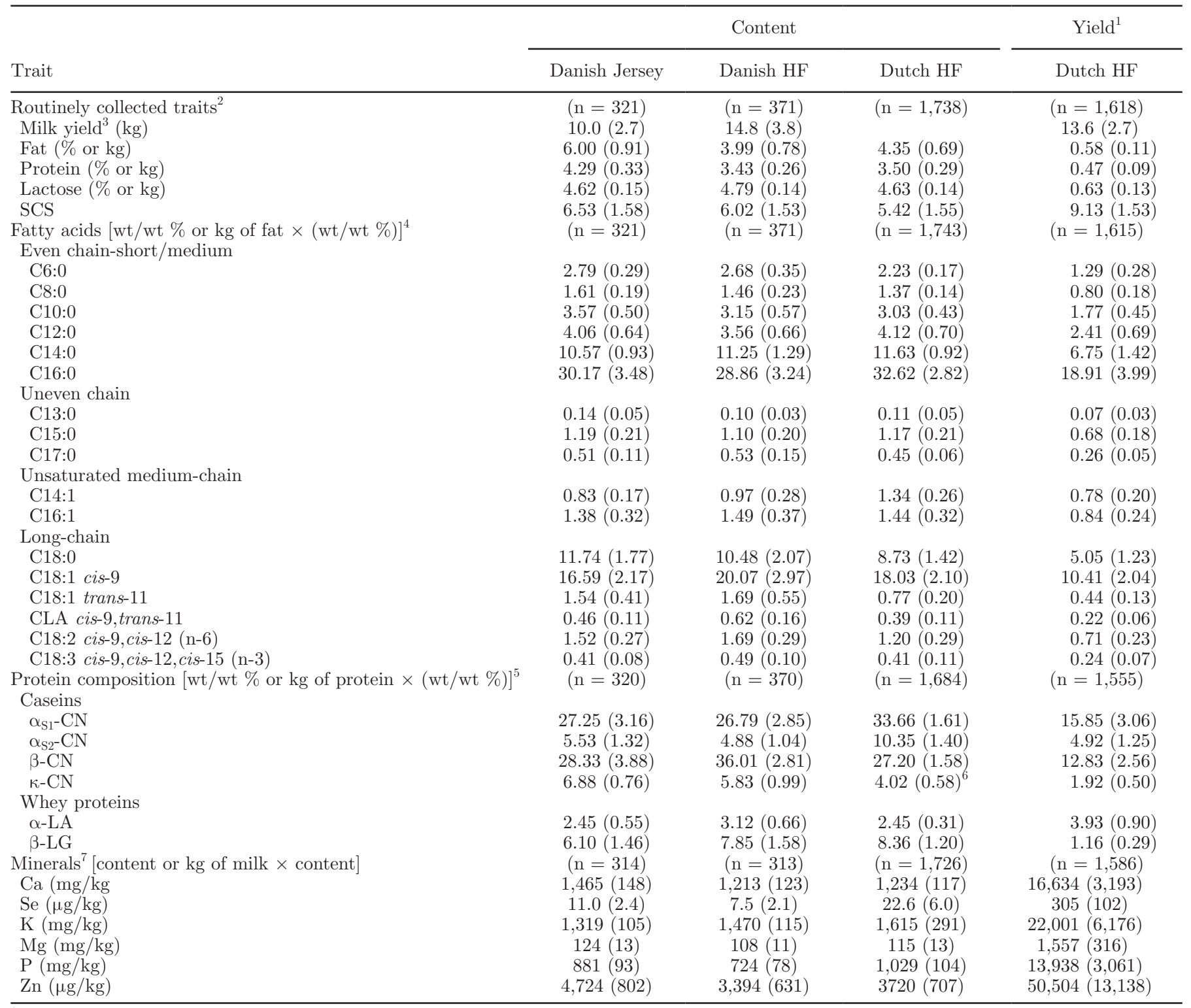

${ }^{1}$ Samples from the Dutch experiment were used to estimate effects of the DGAT1 K232A polymorphism on fatty acid, protein, and mineral yields.

${ }^{2}$ Fat, protein, and lactose are in percent except for Yield column, where values are in kilograms.

${ }^{3}$ Morning milk sample.

${ }^{4}$ Yields of fatty acids were calculated by multiplying fatty acid proportions (wt/wt \%) by kilograms of fat.

${ }^{5}$ Yields of proteins were calculated by multiplying protein proportions (wt/wt \%) by kilograms of protein.

${ }^{6} \mathrm{~K}$-CN-1P (nonglycosylated, monophosphorylated state).

${ }^{7}$ Mineral yields were calculated by multiplying mineral concentrations (in $\mathrm{mg} / \mathrm{kg}$ or $\mu \mathrm{g} / \mathrm{kg}$ ) by kilograms of milk. 


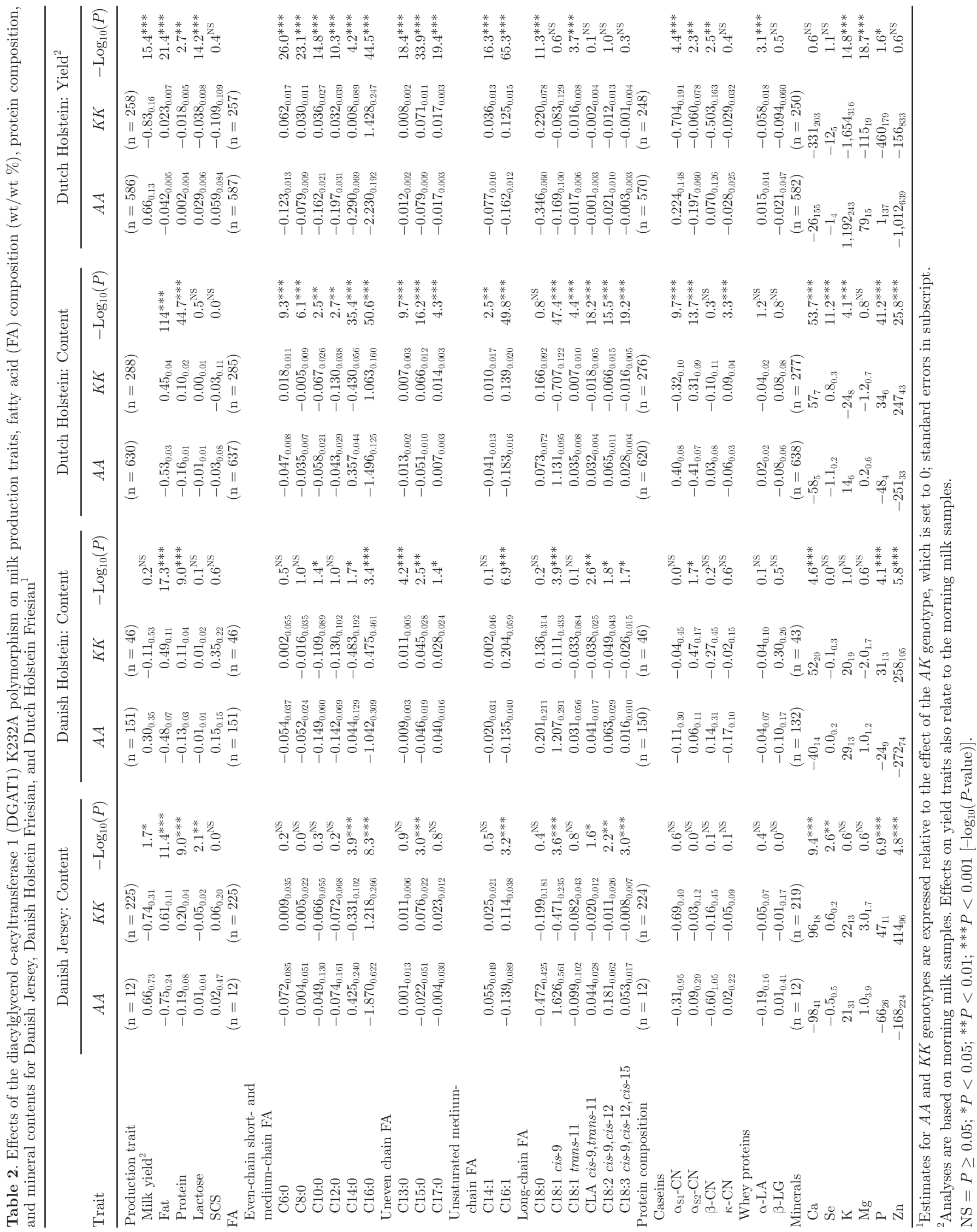


tion quantified consisted of only $\kappa-\mathrm{CN}-1 \mathrm{P}$. The DGAT1 K232A polymorphism did not significantly affect protein composition in the Danish Jersey population (Table 2). In the Danish HF population, a significant effect of the DGAT1 polymorphism on $\alpha_{\mathrm{S}_{2}} \mathrm{CN}$ content was detected. In Dutch HF, significant effects on $\alpha_{\mathrm{S1}^{-}}$ $\mathrm{CN}, \alpha_{\mathrm{S} 2^{-}} \mathrm{CN}$, and $\kappa-\mathrm{CN}$ were detected, where the $K$ allele was associated with lower contents of $\alpha_{\mathrm{S1}^{-}} \mathrm{CN}$, and higher contents of $\alpha_{\mathrm{S}^{2}} \mathrm{CN}$ and $\kappa-C N$. Significant effects of the DGAT1 polymorphism on total yields of $\alpha_{\mathrm{S}^{-}} \mathrm{CN}, \alpha_{\mathrm{S}^{2}} \mathrm{CN}, \beta-\mathrm{CN}$, and $\alpha-\mathrm{LA}$ were found. The $K$ allele was associated with lower yields, especially of $\alpha_{S 1^{-}}$ $\mathrm{CN}$ and $\beta-\mathrm{CN}$.

\section{Mineral Contents}

Danish Jerseys had higher $\mathrm{Ca}, \mathrm{Mg}$, and Zn contents in milk compared with Danish HF and Dutch HF (Table 1). Dutch HF had higher Se, K, and P contents than Danish Jerseys and Danish HF. The DGAT1 K232A polymorphism had highly significant effects on $\mathrm{Ca}, \mathrm{P}$, and $\mathrm{Zn}$ in all 3 populations: the $K$ allele was consistently associated with higher contents (Table 2). In the Dutch HF population, the contribution of the DGAT1 K232A polymorphism to the phenotypic variance (based on Table 1) was $12.0 \%$ for Ca, $8.3 \%$ for P, and $6.1 \%$ for $\mathrm{Zn}$

Total Ca and $\mathrm{Zn}$ output in milk (i.e., yield), however, were not significantly affected by the DGAT1 polymorphism, and the effect on total $\mathrm{P}$ output was significant but small. In contrast, the DGAT1 polymorphism had no significant effect on $\mathrm{Mg}$ content in the 3 populations but there was a significant effect on total $\mathrm{Mg}$ output in milk, where the $K$ allele was associated with a lower output. A significant effect on Se content in milk was detected in Danish Jersey and Dutch HF, where the $K$ allele was associated with higher levels, but the effect was not significant in Danish HF. Total Se output in milk was not significantly affected by the DGAT1 polymorphism. In the Dutch HF population, the DGAT1 polymorphism also had a significant effect on $\mathrm{K}$ content and total $\mathrm{K}$ output in milk, where the $K$ allele was associated with a lower level and a lower output. The effect on $\mathrm{K}$ content, however, was not confirmed in the Danish Jersey or Danish HF population.

\section{DISCUSSION}

This study shows the effects of the DGAT1 K232A polymorphism on detailed FA, protein, and mineral composition of dairy cattle milk. Previously, several studies reported major effects of the DGAT1 polymorphism on routinely collected milk production traits; however, little is known about effects of the DGAT1 polymorphism on detailed milk composition. Using unique phenotypes collected as part of the Dutch and Danish-Swedish Milk Genomics Initiatives, we showed in this study that the DGAT1 polymorphism was significantly and consistently associated with FA and mineral composition of milk.

\section{Fat}

Several studies have shown that the DGAT1 $K$ allele is associated with higher fat content and fat yield (e.g., Grisart et al., 2002; Winter et al., 2002), and these effects are confirmed in this study. In addition, we report significant effects of the DGAT1 polymorphism on the contents of C14:0, C16:0, C15:0, C16:1, C18:1 cis-9, CLA cis-9,trans-11, C18:2 cis-9,cis-12 (n-6), and C18:3 cis-9, cis-12, cis-15 (n-3), which were consistent across breeds and countries. However, yields of C18:1 cis-9, CLA, n-6, and n-3 were not affected by the DGAT1 polymorphism. The $K$ allele of DGAT1 was associated with increased de novo FA yields and, as a consequence, the contribution (wt/wt \%) of C18:1 cis-9, CLA, n-6, and n-3 to total fat was reduced. The significant effects of the DGAT1 polymorphism on the contents of these FA are, therefore, indirect rather than direct effects. However, effects of the DGAT1 polymorphism on C18:1, CLA, n-6, and n-3 FA might be of practical relevance as FA composition affects the physical and functional properties of butter and products rich in milk fat (Parodi, 1979; Hawke and Taylor, 1995). Furthermore, milk fat from DGAT1 $A A$ cows contained less C16:0 and more CLA cis-9,trans-11 and C18:3 cis-9,cis-12,cis-15 than milk fat from $K K$ cows and is, therefore, favored from the perspective of human health (e.g., Mensink et al., 2003).

\section{Protein}

Several studies have shown that the DGAT1 $K$ allele is associated with higher protein content but lower protein yield (e.g., Grisart et al., 2002; Winter et al., 2002), and these results are confirmed in this study. In addition, we found significant effects of the DGAT1 polymorphism on $\alpha_{\mathrm{S}_{1}}-\mathrm{CN}, \alpha_{\mathrm{S}^{2}} \mathrm{CN}, \kappa-\mathrm{CN}$, and $\alpha$-LA contents in Dutch HF. Only the effect on $\alpha_{\mathrm{S}_{2}} \mathrm{CN}$ content was confirmed in Danish HF. The difficulty in confirming effects of the DGAT1 polymorphism on milk protein composition in Danish Jersey or Danish HF might be related to the lower detection power for these populations. Significant effects on the yields of $\alpha_{\mathrm{S} 1}-\mathrm{CN}, \alpha_{\mathrm{S} 2}-\mathrm{CN}, \beta-\mathrm{CN}$, and $\alpha$-LA indicated decreased production of $\alpha_{\mathrm{S}^{-}} \mathrm{CN}, \beta-\mathrm{CN}$, and $\alpha-\mathrm{LA}$ associated with the DGAT1 $K$ allele. In Dutch HF, it has been shown that DGAT1 has an effect on $\alpha_{\mathrm{S} 1}-\mathrm{CN}-9 \mathrm{P}$ but 
not on $\alpha_{\mathrm{S} 1}-\mathrm{CN}-8 \mathrm{P}$, suggesting an effect of DGAT1 on the posttranslational phosphorylation of $\alpha_{\mathrm{S} 1}-\mathrm{CN}$ (Bijl et al. 2014). These effects could not be verified in the Danish HF or Danish Jersey as $\alpha_{\mathrm{S}_{1}}-\mathrm{CN}-9 \mathrm{P}$ has not been measured in these populations.

\section{Minerals}

van Hulzen et al. (2009) showed that mineral content of milk is strongly affected by genetic factors. This study shows that part of this genetic variation can be attributed to the DGAT1 K232A polymorphism. Effects of the DGAT1 polymorphism on $\mathrm{Ca}$, P, and $\mathrm{Zn}$ contents in milk were highly significant and consistent across the 3 populations. The total amounts of $\mathrm{Ca}, \mathrm{P}$, and $\mathrm{Zn}$ excreted in milk, however, were not affected by the DGAT1 polymorphism. Therefore, effects on $\mathrm{Ca}$, $\mathrm{P}$, and $\mathrm{Zn}$ content can be explained by effects of the DGAT1 polymorphism on milk volume; compared with DGAT1 $A A$, the same amount of $\mathrm{Ca}, \mathrm{P}$, and $\mathrm{Zn}$ was excreted by the $K K$ cows but in a smaller volume of milk and consequently the content of $\mathrm{Ca}, \mathrm{P}$, and $\mathrm{Zn}$ was higher for $K K$ cows ("dilution effect"). Apparently, the excretion of $\mathrm{Mg}$ (and to a lesser extent also $\mathrm{K}$ ) was downregulated when the milk volume decreased whereas this was not the case for $\mathrm{Ca}, \mathrm{P}$, and $\mathrm{Zn}$.

On average, approximately $70 \%$ of $\mathrm{Ca}, 50 \%$ of inorganic $\mathrm{P}$, and $30 \%$ of $\mathrm{Mg}$ are located in the casein micelles and contents of these milk minerals are proportional to protein content (e.g., Gaucheron, 2005; Bijl et al., 2013). Therefore, higher contents of $\mathrm{Ca}, \mathrm{P}$, and $\mathrm{Mg}$ in milk of DGAT1 $K K$ cows, which have higher protein contents, would have been expected. For $\mathrm{Ca}$ and $\mathrm{P}$, this was the case in our study; however, $\mathrm{Mg}$ content was not affected by the DGAT1 polymorphism. Further, we detected no significant effect of the DGAT1 polymorphism on total output of $\mathrm{Ca}$ and $\mathrm{P}$, whereas protein yield was affected. This indicates that the effects of the DGAT1 polymorphism on $\mathrm{Ca}, \mathrm{P}$, and $\mathrm{Mg}$ cannot be fully explained by effects of the DGAT1 polymorphism on milk protein production and suggests that DGAT1 also affects the distribution of these milk salts between casein micelles and milk serum. Such changes in distribution of milk salts could influence the structure of casein micelles and manufacturing properties. There is, however, no evidence that the DGAT1 polymorphism affects technological properties important for cheese production (Glantz et al., 2011).

\section{Genotypes}

Genotypes for the DGAT1 K232A polymorphism were not available for the Danish cows but they were genotyped for SNP marker ARS-BFGL-NGS-4939 (rs109421300) instead. The LD analysis showed that ARS-BFGL-NGS-4939 was located in the same haplotype block as the DGAT1 polymorphism. This agrees with Wang et al. (2012), who showed that in German Holsteins there is almost complete LD between DGAT1 K232A and ARS-BFGL-NGS-4939 (squared correlation coefficient, $\left.r^{2}=0.998\right)$. Wang et al. (2012) indicated that not observing complete LD between both polymorphisms was probably the consequence of inaccurate imputation of genotypes for 2 individuals. Furthermore, ARS-BFGL-NGS-4939 was reported to be the most significant SNP for fat content in both the Danish HF and the Danish Jersey populations in Buitenhuis et al. (2014) as well as in other studies (Cole et al., 2011; Raven et al., 2014). Therefore, ARS-BFGL-NGS-4939 is considered a good proxy for the DGAT1 K232A polymorphism.

\section{Significant and Consistent Effects}

Some studies have suggested that the LD region of BTA14 contains other mutations besides the DGAT1 K232A polymorphism that affect milk composition (e.g., Bennewitz et al., 2004; Kühn et al., 2004; Gautier et al., 2007). In the current study, we focused on effects of the DGAT1 polymorphism that were significant in all 3 populations and for which estimated effects were consistent; that is, the favorable allele was identical. It is expected that results that are significant and consistent across breeds (e.g., Raven et al., 2014) are more likely to be true effects of the DGAT1 K232A polymorphism rather than being effects of linked QTL.

More significant effects of the DGAT1 polymorphism were detected in the Dutch HF population than in the Danish Jersey or Danish HF populations. This was likely due to the larger sample size of the Dutch HF population and, additionally, because of the lower detection power because of low frequency of the DGAT1 $A$ allele in Danish Jersey.

Confirmation of effects of the DGAT1 polymorphism in the 3 populations may have been hindered by differences in generating phenotypes (i.e., analytical methods) in the Dutch and Danish studies or by differences in nongenetic effects (e.g., feeding regimens) between Dutch and Danish farms. This is especially true for differences between Danish and Dutch HF because genetic differences between these 2 HF populations are expected to be small. Milk protein and mineral compositions were determined using different analytical methods in the Dutch and Danish studies, but milk FA composition was analyzed using GC in both studies. However, Contarini et al. (2013) pointed out some of the problems that can be encountered when standardizing FA analyses across different laboratories using GC, even if 
laboratories are highly experienced. In this study, the relatively large differences for $\mathrm{C} 18: 1$ trans-11 between Dutch and Danish HF can be attributed to differences in the analytical method: in the Danish milk samples, the peak assigned as $\mathrm{C} 18: 1$ trans-11 was a mixture of trans-10 and trans-11 isomers. Higher content of C12:0 in Dutch HF compared with Danish HF might be due to feeding concentrates with palm kernel expeller and extracted coconut on Dutch farms (Heck et al., 2012).

Variations in milk protein composition due to herd differences are relatively small (Schopen et al., 2009) and much lower than for milk FA (Stoop et al., 2008). Therefore, differences in protein composition between Danish and Dutch HF were more likely the result of differences between the CZE and LC/ESI-MS methods than due to differences in feeding regimens. In this study, $\kappa-\mathrm{CN}$ in Dutch HF was underestimated, as only the monophosphorylated (1P) form was detected by CZE.

The effect of differences in analytical methods between the 2 studies and feeding regimens between the 2 countries on estimated effects of the DGAT1 polymorphism is unknown. Duchemin et al. (2013) showed for Dutch HF that, despite considerable differences in milk FA composition between winter and summer, effects of the DGAT1 polymorphism were very similar in both seasons. This is in line with effects of the DGAT1 polymorphism on milk FA and milk mineral composition in the 3 populations in our study, despite potential differences in analytical methods and feeding regimens between the Dutch and Danish studies

\section{Breed Differences}

Poulsen et al. (2012) analyzed feeding regimens of the Danish Jersey and Danish HF used in this study and concluded that these were very similar. Further, milk composition for Danish Jersey and Danish HF has been analyzed using the same analytical methodologies. Therefore, observed phenotypic differences in milk composition between Danish Jersey and Danish HF most likely reflect breed differences. Part of these differences in milk composition can be explained by differences in allele frequencies of the DGAT1 K232A polymorphism between Danish Jersey and Danish HF: frequency of the $K$ allele is 0.83 in Danish Jersey and 0.36 in Danish HF. Depending upon whether estimated effects from Danish Jersey or Danish HF are used, 20 to $30 \%$ of the phenotypic difference in fat content between both breeds can be explained by differences in allele frequencies of the DGAT1 polymorphism. For C14:0 this is 40 to $50 \%$, for C16:0 it is 50 to $100 \%$, and for $\mathrm{C} 15: 0$ it is 50 to $60 \%$. Furthermore, 18 to $36 \%$ of the phenotypic difference in $\mathrm{Ca}, 17$ to $33 \%$ of the phenotypic differ- ence in $\mathrm{P}$, and 19 to $22 \%$ of the phenotypic difference in Zn between Danish Jersey and Danish HF can be explained by differences in DGAT1 allele frequencies.

For milk components significantly affected by the DGAT1 polymorphism, the allele associated with higher contents was always at a higher frequency in the breed with the highest phenotypic level, except for C16:1. Estimated effects for DGAT1 indicated that the $K$ allele is consistently associated with higher levels of C16:1. Based on the higher frequency of the DGAT1 allele in the Danish Jersey population it was, therefore, expected that the mean content of $\mathrm{C} 16: 1$ would be higher in Danish Jersey than in Danish HF. Surprisingly, C16:1 content was 1.38 (wt/wt \%) in Danish Jersey and 1.49 (wt/wt \%) in Danish HF. The DGAT1 $K$ allele was associated with higher de novo FA synthesis and, in line with a higher frequency of the $K$ allele, C16:0 content was higher in Danish Jersey (30.17 wt/ wt \%) than in Danish HF (28.86 wt/wt \%). Apparently, a smaller fraction of C16:0 is desaturated by stearoyl CoA desaturase (SCD1) to C16:1 in Danish Jersey compared with Danish HF. This can be explained by differences in allele frequencies of the SCD1 A293V polymorphism between Jersey and HF; frequency of the SCD1 $A$ allele in Jersey is 0.94 to 0.95 (Kgwatalala et al., 2007; Milanesi et al., 2008), whereas this frequency is 0.72 in HF (Schennink et al., 2008). The $A$ allele of SCD1 is associated with lower levels of C16:1 compared with the SCD1 $V$ allele. Less efficient desaturation by SCD1 in Jersey will not only affect C16:1 content but is expected to give a higher $\mathrm{C} 16: 0$ content.

\section{Lactation Stage}

The estimated difference between DGAT1 $K K$ and $A A$ genotypes on fat content is about $1 \%$ for Dutch and Danish HF and $1.36 \%$ for Danish Jersey. Estimates reported in other studies range between 0.6 and $0.8 \%$ (e.g., Grisart et al., 2002; Winter et al., 2002; Spelman et al., 2002; Thaller et al., 2003; Weller et al., 2003; Gautier et al., 2007; Berry et al., 2010) and are considerably lower than those in this study. Bovenhuis et al. (2015) showed for Dutch HF that the difference in fat content between DGAT1 $K K$ and $A A$ is about $0.8 \%$ when estimates are based on test-day records collected throughout lactation, which is in line with estimates reported in other studies. The difference between both estimates (1 vs. $0.8 \%$ ) for Dutch HF can be explained by the interaction between the DGAT1 polymorphism and lactation stage (Bovenhuis et al., 2015): effects of the DGAT1 polymorphism on fat content in early lactation are smaller than effects in mid and late lactation. Similar to fat content, estimates reported in this study for FA, protein, and mineral composition apply 
to cows in mid and late lactation, and these estimates might differ from estimates based on records collected throughout lactation.

We evaluated DGAT1 $\times$ lactation stage interaction for FA, protein, and mineral composition in the Dutch HF population (i.e., the data set with the largest number of observations). No significant DGAT1 $\times$ lactation stage interactions were detected for FA composition. Indications for a DGAT1 $\times$ lactation stage interaction were detected for $\alpha_{\mathrm{S}_{2}} \mathrm{CN}(P=0.04)$, Se $(P=0.02)$, and Zn $(P=0.04)$. The lack of highly significant DGAT1 $\times$ lactation stage interactions for detailed milk composition might be due to the absence of early-lactation test-day records, as it seems that effects of the DGAT1 polymorphism change mainly in early lactation (Bovenhuis et al., 2015).

In this study, we showed that the DGAT1 K232A polymorphism has major effects on FA and mineral composition of bovine milk. These effects are relevant in relation to cow health, human health, and functional properties of milk fat and milk protein. Nutritional recommendations for dairy cattle do not account for differences between cows in milk mineral content and assume milk mineral content is constant. Knowledge of DGAT1 genotypes can assist in more accurate assessment of requirements of $\mathrm{Ca}, \mathrm{P}$, and $\mathrm{Zn}$ of individual cows. Intake of n-3 C18:3 cis-9,cis-12,cis-15 FA, and Zn have been related to human health (e.g., Hambidge and Krebs, 2007; German et al., 2009; Mozaffarian et al., 2010). Higher intake of n-3 FA can be achieved with milk fat from DGAT1 $A A$ cows, and higher intake of Zn can be achieved with milk from DGAT1 $K K$ cows. Further, differences in milk FA composition between DGAT1 genotypes have consequences for the functional properties of milk fat, and effects of the DGAT1 polymorphism on caseins and milk salts could influence the composition and size of casein micelles and, consequently, functional properties of milk protein

\section{ACKNOWLEDGMENTS}

H. B. was supported by a grant of Aarhus University Research Foundation (Tjele, Denmark; no. R26 A2220). Collection of the Dutch data was part of the Dutch Milk Genomics Initiative, funded by Wageningen University (Wageningen, the Netherlands), the Dutch Dairy Association NZO (Zoetermeer, the Netherlands), Cooperative Cattle Improvement Organization CRV (Arnhem, the Netherlands), and the Dutch Technology Foundation STW (Utrecht, the Netherlands). The collection of the Danish data was part of the DanishSwedish Milk Genomics Initiative funded by Arla Foods (Viby J, Denmark), the Danish Cattle Federa- tion (Skejby, Denmark), the Danish Strategic Research Council (Copenhagen, Denmark), Aarhus University (Aarhus, Denmark), and the Milk Levy Fund (Skejby, Denmark) through the projects "Milk Genomics" and "Phenotypic and genetic markers for specific milk quality parameters."

\section{REFERENCES}

Barrett, J. C., B. Fry, J. Maller, and M. J. Daly. 2005. Haploview: Analysis and visualization of LD and haplotype maps. Bioinformatics 21:263-265.

Bennewitz, J., N. Reinsch, S. Paul, C. Looft, B. Kaupe, C. Weimann, G. Erhardt, G. Thaller, Ch. Kühn, M. Schwerin, H. Thomsen, F. Reinhardt, R. Reents, and E. Kalm. 2004. The DGAT1 K232A mutation is not solely responsible for the milk production quantitative trait locus on the bovine chromosome 14. J. Dairy Sci. $87: 431-442$

Berry, D. P., D. Howard, P. O'Boyle, S. Waters, J. F. Kearney, and M. McCabe. 2010. Associations between the K232A polymorphism in the diacylglycerol-O-transferase 1 (DGAT1) gene and performance in Irish Holstein-Friesian dairy cattle. Ir. J. Agric. Food Res. 49:1-9.

Bijl, E., H. J. F. van Valenberg, T. Huppertz, and A. C. M. van Hooijdonk. 2013. Protein, casein, and micellar salts in milk: Current content and historical perspectives. J. Dairy Sci. 96:5455-5464.

Bijl, E., H. J. F. van Valenberg, T. Huppertz, A. C. M. van Hooijdonk, and H. Bovenhuis. 2014. Phosphorylation of $\alpha_{\mathrm{S}_{1}}$-casein is regulated by different genes. J. Dairy Sci. 97:7240-7246.

Bovenhuis, H., M. H. P. W. Visker, H. J. F. van Valenberg, A. J. Buitenhuis, and J. A. M. van Arendonk. 2015. Effects of the DGAT1 polymorphism on test-day milk production traits throughout lactation. J. Dairy Sci. 98:6572-6582.

Buitenhuis, A. J., U. K. Sundekilde, N. A. Poulsen, H. C. Bertram, L. B. Larsen, and P. Sørensen. 2013. Estimation of genetic parameters and detection of quantitative trait loci for metabolites in Danish Holstein milk. J. Dairy Sci. 96:3285-3295.

Buitenhuis, B., L. L. G. Janss, N. A. Poulsen, L. B. Larsen, M. K. Larsen, and P. Sørensen. 2014. Genome-wide association and biological pathway analysis for milk-fat composition in Danish Holstein and Danish Jersey cattle. BMC Genomics 15:1112.

Buitenhuis, B., N. A. Poulsen, L. B. Larsen, and J. Sehested. 2015. Estimation of genetic parameters and detection of quantitative trait loci for minerals in Danish Holstein and Danish Jersey milk. BMC Genet. 16:52.

Cole, J. B., G. R. Wiggans, L. Ma, T. S. Sonstegard, T. J. Lawlor Jr., B. A. Crooker, C. P. Van Tassell, J. Yang, S. Wang, L. K. Matukumalli, and Y. Da. 2011. Genome-wide association analysis of thirty one production, health, reproduction and body conformation traits in contemporary U.S. Holstein cows. BMC Genomics 12:408.

Contarini, G., M. Povolo, V. Pelizzola, L. Monti, and G. Lercker. 2013. Interlaboratory evaluation of milk fatty acid composition by using different GC operating conditions. J. Food Compos. Anal. 32:131-140.

Duchemin, S., H. Bovenhuis, W. M. Stoop, A. C. Bouwman, J. A. M. van Arendonk, and M. H. P. W. Visker. 2013. Genetic correlation between composition of bovine milk fat in winter and summer, and DGAT1 and SCD1 by season interactions. J. Dairy Sci. 96:592-604.

Gaucheron, F. 2005. The minerals of milk. Reprod. Nutr. Dev. 45:473483.

Gautier, M., A. Capitan, S. Fritz, A. Eggen, D. Boichard, and T. Druet. 2007. Characterization of the DGAT1 K232A and variable number of tandem repeat polymorphisms in French dairy cattle. J. Dairy Sci. 90:2980-2988.

German, J. B., R. A. Gibson, R. M. Krauss, P. Nestel, B. Lamarche, W. A. van Staveren, J. M. Steijns, L. C. P. G. M. de Groot, A. 
L. Lock, and F. Destaillats. 2009. A reappraisal of the impact of dairy foods and milk fat on cardiovascular disease risk. Eur. J. Nutr. 48:191-203.

Gilmour, A. R., B. Gogel, B. Cullis, and R. Thompson. 2009. ASReml User Guide Release 3.0. VSN International Ltd., Hemel Hempstead, UK.

Glantz, M., H. Lindmark Månsson, H. Stålhammar, and M. Paulsson. 2011. Effect of polymorphisms in the leptin, leptin receptor, and acyl-coenzyme A:diacylglycerol acyltransferase 1 (DGAT1) genes and genetic polymorphism of milk proteins on cheese characteristics. J. Dairy Sci. 94:3295-3304.

Grisart, B., W. Coppieters, F. Farnir, L. Karim, C. Ford, P. Berzi, N. Cambisano, M. Mni, S. Reid, P. Simon, R. Spelman, M. Georges, and R. Snell. 2002. Positional candidate cloning of a QTL in dairy cattle: identification of a missense mutation in the bovine DGAT1 gene with major effect on milk yield and composition. Genome Res. 12:222-231.

Hambidge, K. M., and N. F. Krebs. 2007. Zinc Deficiency: A Special Challenge. J. Nutr. 137:1101-1105.

Hawke, J. C., and M. W. Taylor. 1995. Influence of nutritional factors on yield, composition and physical properties of milk fat. Pages 37-38 in Advanced Dairy Chemistry. Vol. 2. Lipids. Chapman and Hall, London, UK.

Heck, J. M. L., R. C. R. Meuldijk, H. Bovenhuis, J. Dijkstra, H. J. F. van Valenberg, and A. C. M. van Hooijdonk. 2012. Genetic and herd parameters for milk fatty acid composition. J. Dairy Res. 79:39-46.

Heck, J. M. L., C. Olieman, A. Schennink, H. J. F. van Valenberg, M. H. P. W. Visker, R. C. R. Meuldijk, and A. C. M. van Hooijdonk. 2008. Estimation of variation in concentration, phosphorylation and genetic polymorphism of milk proteins using capillary zone electrophoresis. Int. Dairy J. 18:548-555.

Jensen, H. B., N. A. Poulsen, K. K. Andersen, M. Hammershøj, H. D. Poulsen, and L. B. Larsen. 2012. Distinct composition of bovine milk from Jersey and Holstein-Friesian cows with good, poor, or non-coagulation properties as reflected in protein genetic variants and isoforms. J. Dairy Sci. 95:6905-6917.

Kgwatalala, P. M., E. M. Ibeagha-Awemu, J. F. Haves, and X. Zhao. 2007. Single nucleotide polymorphisms in the open reading frame of the stearoyl-CoA desaturase gene and resulting genetic variants in Canadian Holstein and Jersey cows. DNA Seq. 18:357-362.

Kühn, C., G. Thaller, A. Winter, O. R. P. Bininda-Emonds, B. Kaupe, G. Erhardt, J. Bennewitz, M. Schwerin, and R. Fries. 2004. Evidence for multiple alleles at the DGAT1 locus better explains a quantitative trait locus with major effect on milk fat content in cattle. Genetics 167:1873-1881.

Larsen, T., M. K. Larsen, and N. C. Friggens. 2011. Enzymatic and fluorometric determination of triacylglycerols in cow milk and other opaque matrices. Food Chem. 125:1110-1115.

Mensink, R. P., P. L. Zock, A. D. M. Kester, and M. B. Katan. 2003. Effects of dietary fatty acids and carbohydrates on the ratio of serum total to HDL cholesterol and on serum lipids and apolipoproteins: A meta-analysis of 60 controlled trials. Am. J. Clin. Nutr. 77:1146-1155.

Milanesi, E., L. Nicoloso, and P. Crepaldi. 2008. Stearoyl CoA desaturase (SCD) gene polymorphisms in Italian cattle breeds. J. Anim. Breed. Genet. 125:63-67.

Mozaffarian, D., R. Micha, and S. Wallace. 2010. Effects on coronary heart disease of increasing polyunsaturated fat in place of saturated fat: A systematic review and meta-analysis of randomized controlled trials. PLoS Med. 7:e1000252.
NRC. 2001. Nutrient Requirements of Dairy Cattle. 7th rev. ed. Natl. Acad. Press, Washington DC.

Parodi, P. W. 1979. Relationship between tri-saturated glyceride composition and the softening point of milk-fat. J. Dairy Res. 46:633639

Poulsen, N. A., F. Gustavsson, M. Glantz, M. Paulsson, L. B. Larsen, and M. K. Larsen. 2012. The influence of feed and herd on fatty acid composition in 3 dairy breeds (Danish Holstein, Danish Jersey, and Swedish Red). J. Dairy Sci. 95:6362-6371.

Raven, L.-A., B. G. Cocks, and B. J. Hayes. 2014. Multi-breed genome wide association can improve precision of mapping causative variants underlying milk production in dairy cattle. BMC Genomics 15:62.

Schennink, A., J. M. L. Heck, H. Bovenhuis, M. H. P. W. Visker, H. J. F. Van Valenberg, and J. A. M. van Arendonk. 2008. Milk fatty acid unsaturation: Genetic parameters and effects of stearoyl-CoA desaturase (SCD1) and acyl CoA: Diacylglycerol acyltransferase (DGAT1). J. Dairy Sci. 91:2135-2143.

Schennink, A., W. M. Stoop, M. H. P. W. Visker, J. M. L. Heck, H. Bovenhuis, J. J. van der Poel, H. J. F. van Valenberg, and J. A. M. van Arendonk. 2007. DGAT1 underlies large genetic variation in milk-fat composition of dairy cows. Anim. Genet. 38:467-473.

Schopen, G. C. B., J. M. L. Heck, H. Bovenhuis, M. H. P. W. Visker, H. J. F. van Valenberg, and J. A. M. van Arendonk. 2009. Genetic parameters for major milk proteins in Dutch Holstein-Friesians. J. Dairy Sci. 92:1182-1191.

Schopen, G. C. B., M. H. P. W. Visker, P. D. Koks, E. Mullaart, J. A. M. van Arendonk, and H. Bovenhuis. 2011. Whole genome association study for milk protein composition in dairy cattle. J. Dairy Sci. 94:3148-3158.

Spelman, R. J., C. A. Ford, P. McElhinney, G. C. Gregory, and R. G. Snell. 2002. Characterization of the DGAT1 gene in the New Zealand dairy population. J. Dairy Sci. 85:3514-3517.

Stoop, W. M., J. A. M. van Arendonk, J. M. L. Heck, H. J. F. van Valenberg, and H. Bovenhuis. 2008. Genetic parameters for milk fatty acids and milk production traits of Dutch Holstein Friesians. J. Dairy Sci. 91:385-394.

Thaller, G., W. Krämer, A. Winter, B. Kaupe, G. Erhardt, and R. Fries. 2003. Effects of DGAT1 variants on milk production traits in German cattle breeds. J. Anim. Sci. 81:1911-1918.

van Hulzen, K. J. E., R. C. Sprong, R. van der Meer, and J. A. M. van Arendonk. 2009. Genetic and nongenetic variation in concentration of selenium, calcium, potassium, zinc, magnesium, and phosphorus in milk of Dutch Holstein-Friesian cows. J. Dairy Sci. 92:5754-5759.

Wang, X., C. Wurmser, H. Pausch, S. Jung, F. Reinhardt, J. Tetens, G. Thaller, and R. Fries. 2012. Identification and dissection of four major QTL affecting milk fat content in the German HolsteinFriesian population. PLoS ONE 7:e40711.

Weller, J. I., M. Golik, E. Seroussi, E. Ezra, and M. Ron. 2003. Population-wide analysis of a QTL affecting milk-fat production in the Israeli Holstein population. J. Dairy Sci. 86:2219-2227.

Wilmink, J. B. M. 1987. Adjustment of test-day milk, fat and protein yield for age, season and days-in-milk. Livest. Prod. Sci. 16:335348

Winter, A., W. Kramer, F. A. Werner, S. Kollers, S. Kata, G. Durstewitz, J. Buitkamp, J. E. Womack, G. Thaller, and R. Fries. 2002. Association of a lysine-232/alanine polymorphism in a bovine gene encoding acyl-CoA:diacylglycerol acyltransferase (DGAT1) with variation at a quantitative trait locus for milk fat content. Proc. Natl. Acad. Sci. USA 99:9300-9305. 